Article

\title{
Leopold's Arboretum Needs Upstream Water Treatment to Restore Wetlands Downstream
}

\author{
Joy B. Zedler ${ }^{1,2, *}$, James M. Doherty ${ }^{1}$ and Isabel M. Rojas ${ }^{3}$
}

1 Department of Botany, University of Wisconsin-Madison, 430 Lincoln Dr, Madison, WI 53706, USA; E-Mail: jdohert1@gmail.com

2 University of Wisconsin-Madison Arboretum, 1207 Seminole Highway, Madison, WI 53711, USA

3 Department of Forest and Wildlife Ecology, University of Wisconsin-Madison, 1630 Linden Drive, Madison, WI 53706, USA; E-Mail: rojasviada@wisc.edu

* Author to whom correspondence should be addressed; E-Mail: jbzedler@wisc.edu; Tel.: +1-608-262-8629; Fax: +1-608-262-7509.

Received: 26 November 2013; in revised form: 21 December 2013 / Accepted: 24 December 2013 / Published: 2 January 2014

\begin{abstract}
A case study has broad relevance for urban natural reserves. Aldo Leopold's far-reaching vision to restore historical ecosystems at the UW-Madison Arboretum has been difficult to achieve despite $\sim 80$ years of restoration work. Wetlands $(\sim 1 / 4$ of the 485 -ha reserve) resist restoration, given urban watersheds and inflows of low quality water. Current conditions favor aggressive invasive plants (cattails, reed canary grass, and buckthorn) - species that do not fulfill the 1934 vision. Today, urban runoff flows into remnant natural wetlands, degraded wetlands, the iconic Curtis Prairie, and constructed wetlands. Regulations for total maximum daily loads (TMDLs) have led local municipalities to expand pre-existing sediment- and nutrient-trapping ponds from 5.67 ha (14 ac) of Arboretum land to $9.3 \mathrm{ha}(23 \mathrm{ac})$ to protect downstream lakes. Both the runoff and the treatment facilities (with invasive plants) limit the Arboretum's ability to achieve pre-settlement vegetation. Consistent with Leopold's vision, we endorse Arboretum principles that urban runoff be restored to pre-settlement quality, and we recommend shifting efforts to reduce TMDLs to upstream lands in order to protect the Arboretum. Given that invasive species will persist, Leopold's Arboretum should be rededicated to research, education, and restoration, plus sustainable management of its waters and wetlands.
\end{abstract}


Keywords: biodiversity conservation; Curtis Prairie; invasive species; stormwater management; sustainable management, urban runoff; water quality

\section{Introduction to Aldo Leopold's Arboretum}

Aldo Leopold broadened his understanding of human land abuse during the dust bowl years, and in 1934 he helped dedicate a large nature reserve for the University of Wisconsin-Madison to restore examples of the region's historical prairies, savannas, woodlands, and low-lying lands (hereafter, the Arboretum). Leopold's vision was to provide pre-European-settlement ecosystems for research, education, and human well-being: "The University must now take on the additional function of preserving an environment fit to support citizens" (Leopold 1934 in [1]; Box 1). The historical target seemed feasible, given that Wisconsin's land survey provided early (1833-1866) data on vegetation. Because the chosen site was a farm several kilometers from the university and city center, Leopold might not have anticipated the current situation, namely, a 485-ha green space within an urban sea (Figure 1). The mission, stated in 2000, is to conserve and restore Arboretum lands, advance restoration ecology and foster the land ethic.

The Arboretum case is not unique. Nature reserves, biological field stations, and parks with remnant natural vegetation can be greatly modified by nearby urbanizing lands. Urban wetlands are especially altered by upstream watersheds that are undergoing urbanization, because runoff changes in quantity and quality. Most development occurs sporadically, project by project, and the cumulative impacts go unrecorded. Thus, once threats become noticed by reserve managers, "before data" are not likely to be available, and analyses of impacts during and after development may be unaffordable. While funding may amply support planning and implementation of development projects, nearby reserves might not realize the need to document changes and might not have funding to assess conditions before, during and after land use changes. The experiences of the Arboretum inform other managers of reserves near urban areas by raising issues to address early in the process, namely the need for watershed planning and sustainable management. It also suggests research needs for scientists to pursue and the need for educators to record and disseminate lessons learned.

Box 1. The Arboretum's long legacy of science-based land care began in 1935 with experiments by Norman Fassett (UW Botany Professor) and his graduate student, John Thomson (later a UW Botany Professor). They established native plants in a horse pasture and abandoned fields [2], comparing the spreading of prairie hay with seeding grasses and forbs, and transplanting sod blocks salvaged from remnant prairies that were about to be developed. More species established using sod blocks, but that required more labor. Over the next 75 years, many others added plantings, pulled and herbicided weeds, and burned the emerging prairie to facilitate the spread of native plants [3]. The prairie was later named for John Curtis, UW Botany Professor and author of The Vegetation of Wisconsin. Curtis Prairie now covers $\sim 29.1$ ha (72 ac), of which about $1 / 4$ is wetland.

Nor could Leopold predict the number and types of challenges this reserve would face as the region and the watershed shifted to dense urban land use. The low-lying landscape position led it to receive 
excess urban runoff, laden with sediment, nutrients, and contaminants. Creeks formed and carried the water through Arboretum wetlands into Lake Wingra and beyond, where algal blooms were attributed to nutrient loading [4]. Stormwater retention ponds were installed at the foot of several urban watersheds, beginning in 1969 to slow water, settle solids, and reduce phosphorus (P) flows to downstream waters. Trapping P in Arboretum ponds was expected to make Lake Wingra fit for fish, swimmers and boaters.

Figure 1. The UW-Madison Arboretum (485 ha) is surrounded by urban watersheds, most of which flow into Lake Wingra (7). Other places mentioned here are Curtis Prairie (1); Curtis Pond (2); Gardner Marsh (3); Wingra Fen (4); Wingra Marsh (5); Teal Pond Wetland (6); Lake Wingra (7); Southeast Marsh (8); Greene Prairie (9); Dunn's Marsh (10); and Pond 2 and its adjacent wetland swales (11). Historical remnants $=3,4,5,6$; elevated water levels $=7$ and 9 ; restoration sites $=1,6$ and 9 ; unrestored $=8$; constructed facilities $=2$ and 11 .

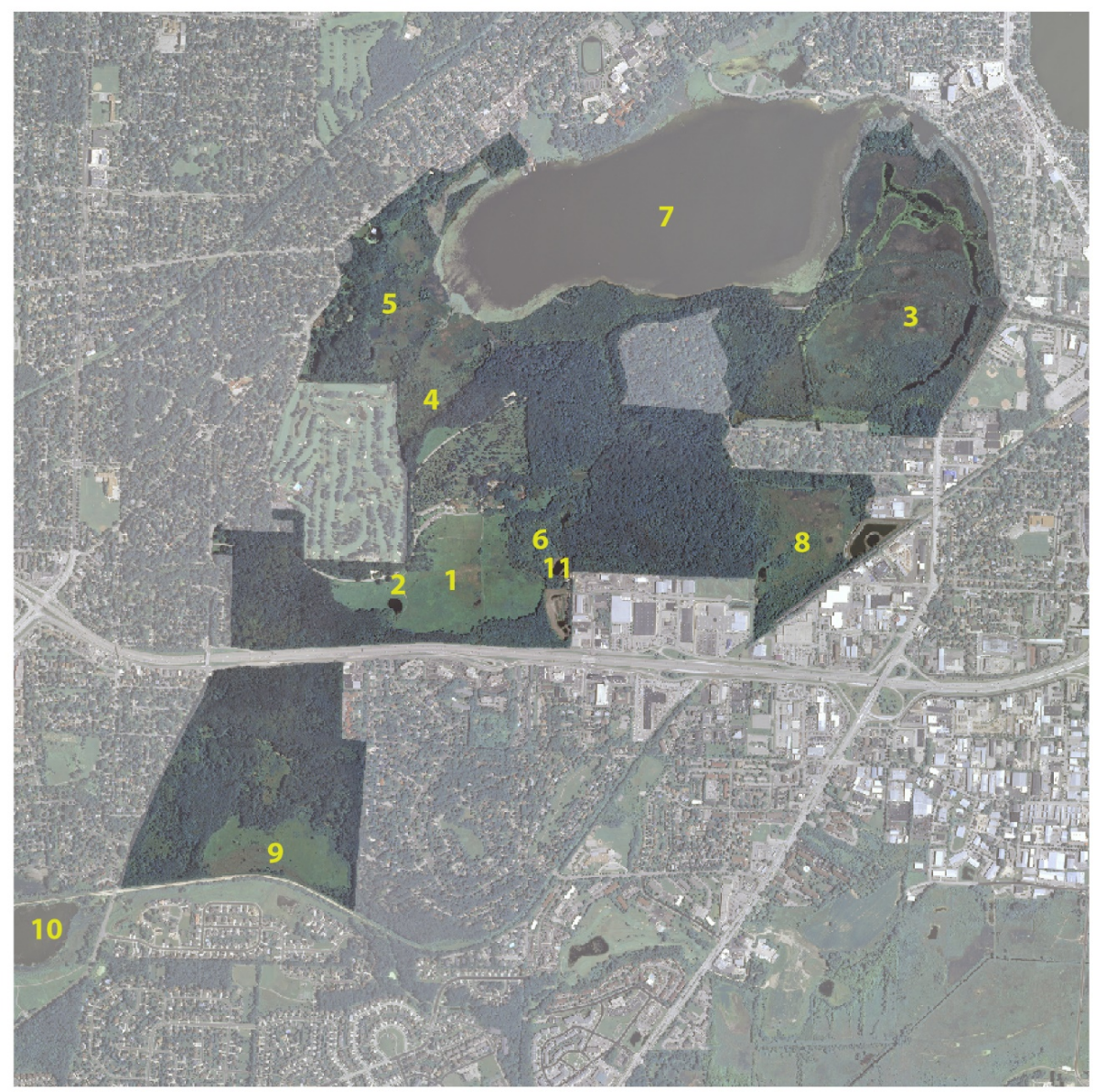

\section{Stormwater Management Issues}

\subsection{Where to Treat Urban Runoff}

Open spaces in general, and those on public lands in particular, are priority locations for installing facilities that are easier to build on flat land that has already been purchased for the public good. The Arboretum accommodated a highway and power lines, despite its mission to restore woodlands, 
prairies and wetlands. Even a copper-wire radio antenna ( 170-m-diameter) was buried in a large wetland to avoid interference from trees, despite scientific arguments that the copper would become toxic in waterlogged soils. Flat, public lands are vulnerable to the siting of public infrastructure.

When stormwater management facilities were under discussion, the Arboretum [5] provided early guidance, including that stormwater: (1) is best managed where the rain falls, before runoff can accumulate; (2) management serve Arboretum restoration objectives, while protecting the environment; and (3) inflow quality be consistent with pre-settlement levels. Nevertheless, multiple structures (mostly retention ponds) were built to reduce sediments and associated $\mathrm{P}$ from flowing through the Arboretum into downstream lakes. The Arboretum case study illustrates the need for watershed planning and treating stormwater closer to its source-upstream from a reserve that is valued for research and education.

\subsection{Conflicts between Stormwater Management and Land Care}

In 1967 limnologists and lake managers met to address lake eutrophication [4]; thereafter, researchers focused on P-removal in runoff flowing toward lakes [6,7]. Few expressed concern about effects of either $\mathrm{P}$ or nitrogen $(\mathrm{N})$ on wetlands located between stormwater ponds and lakes. Nor did managers promise to reduce $\mathrm{N}$ in lakes, knowing that cyanobacteria could fix $\mathrm{N}$ if supplies became limiting. However, Lathrop [8], Lewis and Wurtzbaugh [9] and Paerl [10] all recognized that both $\mathrm{N}$ and $\mathrm{P}$ can stimulate algal blooms, and Bernhardt [11] highlighted the findings of Finlay et al. [12] that lakes actually export $\mathrm{N}$ after $\mathrm{P}$ inflows are reduced. Still, regulations focus on removal of $\mathrm{P}$ or an easily-measured surrogate, total suspended solids (TSS; [13]). Now that the US Environmental Protection Agency is enforcing regulations for total maximum daily loads (TMDLs, emphasizing TSS), municipalities need more sites to construct facilities to remove TSS from urban runoff.

Aerial photos and ground-truthing show urban runoff flowing into the Arboretum at $>10$ points, making its way to Lake Wingra and other downstream waters. When Lake Wingra began experiencing algal blooms in the 1960s, retention ponds were excavated to slow flows and trap sediments and $\mathrm{P}$ around the Arboretum's outer boundary. Around 2000, without testing actual N and P removal, consultants determined that pre-existing ponds should be dredged. The University agreed to have municipalities (primarily the City of Madison) dredge and enlarge retention basins on Arboretum land; in doing so, municipalities gained credit for reducing TMDLs of TSS and associated P. The agreement was not consistent with Arboretum principles [5] or Leopold's vision to allow the soils, waters, plants, and animals (collectively, the land) to exist in their natural state (paraphrasing p. 204 in [14]). Most ponds were enlarged, including one that grew from 0.81 to 2.47 ha (2.0 to $6.5 \mathrm{ac}$ ) where adjacent upland could be excavated without wetland permitting, providing an estimated 63\% TSS-removal. Curtis Pond is scheduled for dredging (as the Wisconsin Department of Natural Resources (DNR) requires as maintenance of existing stormater facilities), but due to the iconic status of Curtis Prairie, this will likely be done without expanding the pond's area. In all, six projects increased construction footprints from 5.67 ha to 9.31 ha (14 to $23 \mathrm{ac}$ ). In a different approach, a storm sewer that discharged runoff into the Arboretum's spring-fed Ho-Nee-Um Pond (Figure 1) was moved north to flow directly into the City's Lake Wingra. This discharge pipe needed repairs, and stormwater was readily diverted to another outfall. 
The construction and operation of greatly enlarged stormwater treatment facilities within Leopold's Arboretum prompted our analysis of existing and alternative approaches. Even though Curtis Pond appears to provide both $\mathrm{P}$ and $\mathrm{N}$ removal (Figure 2), maintenance dredging is still planned for 2014. Dredging plans appear to be based on three assumptions, that (1) P removal is tightly correlated with TSS removal in Curtis Pond; (2) N dynamics are unimportant or untreatable; and (3) removing P well upstream from Lake Wingra will reduce algal blooms downstream. Testing such assumptions requires further research on the actual causes of algal blooms in Lake Wingra. A recent analysis [15] documented a rapid shift from "pea soup" to clear water following carp removal in March 2008. The above assumptions have not stood up to rigorous testing elsewhere [12].

Figure 2. Concentrations of total nitrogen (TN) and total phosphorus (TP) were higher for inflows than outflows of Curtis Pond, and even lower at the culvert where stormwater flows out of Curtis Prairie. Data are based on siphon samplers $(n=4)$ deployed to capture four rainfall events (means for 9 November 2011, 8 March 2012, 23 March 2012, and 20 April 2012; Box 2).

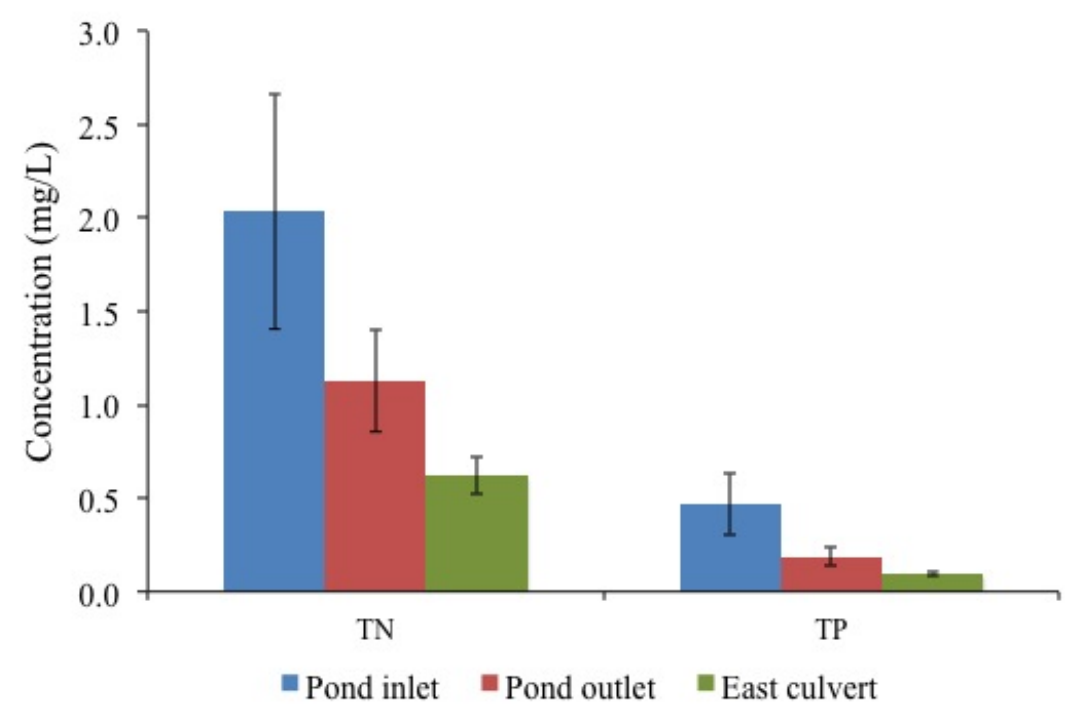

Box 2. In 2011 and 2012 we intermittently sampled water flowing through Curtis Prairie for total and dissolved nitrogen, and total and dissolved phosphorus. In addition, we measured conductivity and estimated total suspended solids (TSS) for samples in spring of 2012. Siphon samplers collected water with higher TSS and nutrient concentrations because they filled at the beginning of the rainfall event as water levels rose to the height of the intake tubes. The highest maximum concentrations of pollutants were found in water samples collected during March 2012, when TN and TP flowing into Curtis Pond were 37 and $0.9 \mathrm{mg} / \mathrm{L}$, respectively. Relying on concentrations, since we did not have flow volumes, there appeared to be a decrease in both $\mathrm{N}$ and TP concentrations between the inflow and the outflow of Curtis Pond. Although TP concentrations were progressively reduced at points sampled along the watercourse, the only significant difference $(p<0.10)$ in TP concentrations based on siphon sample data was between the first point (the inflow of Curtis Pond $(0.471 \pm 0.336 \mathrm{mg} / \mathrm{L})$ and the last point (the Curtis Prairie culvert outflow $(0.094 \pm 0.025 \mathrm{mg} / \mathrm{L})$ to Teal Pond Wetland, indicating that the prairie helped remove $\mathrm{P}$ (see Figure 2). 


\section{Land-Care Benefits and Environmental Costs of Urban Runoff}

Consultants predicted the potential for enlarged stormwater ponds to remove TSS and meet water quality regulations by using models based on settling principles. Such models typically predict removal of dissolved $\mathrm{P}$ or $\mathrm{N}$ via infiltration. Factors affecting $\mathrm{N}$ removal are less well known [12] and difficult to model, especially since complex biological steps are involved in denitrification. Neither the DNR nor the City mandated sampling to document water quality improvement (WQI) or algal blooms in Lake Wingra or other causes of eutrophication (e.g., carp [Cyprinus carpio] that dislodge P from the sediments of Lake Wingra; see [8]). No funds were provided for sampling inflows and outflows of stormwater facilities to determine if they functioned as predicted. The criterion for granting credit for reducing TMDLs of TSS was that the facilities be constructed as designed. That is, assessment was practice based (did the work get done?), not performance based (did the project function as planned?).

The Arboretum's natural, degraded, and constructed wetlands all receive urban runoff and likely contribute to treatment-more by circumstance than by design. The potential effectiveness and sustainability of each wetland's ability to improve water quality likely differs, although data are lacking to quantify such services. Previous maintenance of facilities generally aimed to reduce algal blooms in downstream lakes, which are used for recreational boating, fishing, and swimming. Still, stormwater infrastructures were promoted as ways to protect the Arboretum's restored and natural ecosystems [5].

\subsection{Impacts of Urban Runoff on Natural Wetland Remnants}

Gardner Marsh, Wingra Fen and Marsh, and Teal Pond Wetland (Figure 1) are all remnants of natural wetlands. All receive urban runoff, but there is no sampling to determine levels of pollutants or removal of $\mathrm{N}$ or $\mathrm{P}$. All are shifting toward dominance by invasive plants (Box 3).

Both Gardner Marsh and the Wingra wetlands are being invaded more rapidly than they can be restored [16,17]. Cattails are somewhat controllable where leaves can be burned or cut near the soil, then flooded (as practiced at Horicon Marsh, WI). However, this requires water-level control structures. Herbicides can be effective, but Gardner Marsh no longer has a native-sedge seed bank [16], so newly bare soil would rapidly be recolonized by cattails [18].

Teal Pond Wetland is potentially restorable, now that the dense brush understory (buckthorn and other woody plants) have been mowed (a 2011-2012 project). However, invasive exotics will need control in perpetuity, since reed canary grass (Phalaris arundinacea) and cattails (especially Typha $x$ glauca, a hybrid of the native T. latifolia and the introduced T. angustifolia) are present in the site and in surrounding wetlands. Once seedlings of either species establish, they expand vegetatively. The modal rate for cattail clone-diameter expansion at Mukwonago, WI was $8 \mathrm{~m} /$ year where water levels were artificially stabilized by a dam [19]. Buckthorn (introduced Rhamnus cathartica and R. frangula) is also a continual threat via its bird-dispersed seeds. For native vegetation to become dominant and sustained, perpetual management will be needed.

\subsection{Impacts of Urban Runoff on Degraded Wetlands}

Southeast Marsh receives runoff from two watersheds totaling an estimated 231 acres (93.5 ha), and Lower Greene Prairie drains 390 ac (158 ha; [5]). Invasive plants dominate both lowlands. Nutrient-rich 
inflows likely interacted with historical cultivation to accelerate invasion by reed canary grass and cattails, although both wetlands retain native sedges in small areas that were probably too wet to plow. The mounded topography of tussock sedge (Carex stricta) in both wetlands indicates a lack of cultivation.

Box 3. (1) Once a diverse sedge meadow [20], Gardner Marsh has become dominated by invasive cattails (primarily Typha $x$ glauca) for decades (see Leaflets \#6 and \#11 in [21]). Cattail clones were shown to expand with added nutrients [22] and over time [16], explaining how the cattails advanced an estimated $30 \mathrm{~m}$ in the past decade, outshading some of the last remnants of sedge meadow. In addition, buckthorn (Rhamnus cathartica and R. frangula) dominates the spoils that were sidecast while excavating channels and a lagoon to improve water flow and provide waterfowl habitat.

(2) Wingra Fen was once a raised peat mound just upslope from Wingra Marsh. Wingra Fen has recently succumbed to a cattail invasion, and Wingra Marsh is widely invaded by reed canary grass (Phalaris arundinacea), with some cattails and common reed (Phragmites australis). The fen was sampled by John Curtis as one of 5 fens that comprise his database for Wisconsin fens, and it was sampled again in 1998, when it still had several fen species [23]. Within the past 5 years, however, it converted to a cattail marsh. Why? Groundwater pumping (presumably for the adjacent golf course) was suggested by water level records that revealed drawdowns at night - whereas natural fens would show daytime drawdown via water loss from transpiration with nighttime recharge. Nighttime pumping could have lowered the water table, aerated the surface peat, accelerated peat decomposition, and allowed the fen surface to slump enough to hold water after rainfall. With ponded water, cattail seeds would have germinated readily, followed by vegetative expansion. Wingra Marsh is similarly undergoing "cattailization."

Upstream from Wingra Marsh and Secret Pond (a historical wetland), the City's much-enlarged stormwater pond (about 2 acres) was installed with a $300 \mathrm{ft}(\sim 100-\mathrm{m})$ conveyance flume ending in a "quieting pond" where engineers opted to dredge and remove peat, against regulatory guidance. UW delayed its request for a wetland-fill permit until after plans were nearly final. DNR granted the permit, despite lack of compliance with Clean Water Act guidelines.

(3) Teal Pond Wetland was a sedge meadow when an aerial photo was taken in 1937, but by 2012 it had converted to dominance by European alder (accidentally introduced; plants were thought to be the native species) and widely-dispersed trees and shrubs, including cottonwoods and box elder (wind-dispersed) and buckthorn (seeds dispersed by birds that eat the berries). A bermed fire lane surrounding the wetland ponded some water within Curtis Prairie and funneled the remaining runoff through a culvert, likely altering the historical hydroperiod. Thanks to volunteer work teams and a forest mower, about 12 ac (4.9 ha) of woody plants were cleared for restoration of wet meadow vegetation. Field experiments are underway, testing the importance of tussock topography, seeding, and other measures to restore sedge meadow. The potential of the site to favor native plants over invasive reed canary grass and cattails will likely depend on the quality of water exiting Curtis Prairie and Pond 2, and the Arboretum's ability to use prescribed burns to slow woody plant re-invasion.

The small stormwater pond in Southeast Marsh ( 0.81 ha) intercepted runoff for several years; then its berm eroded so it no longer held water, and it converted to reed canary grass [24]. In 1999, a new berm was constructed along the north boundary of the marsh to protect nearby homes from flooding 
(Figure 1). Sediment excavation for that berm left a trench that ponded water and allowed cattail invasion. Cattails also expanded where heavy equipment left a depression that became a pond after a radio tower there was rebuilt and the antenna buried; contractors failed to use the required swamp mats. Cattails invaded wherever facilitated by runoff and nutrients from the watershed. In addition, cattails invaded the enlarged stormwater pond (now 2.47 ha; see Section 3.4). Southeast Marsh is largely dominated by reed canary grass and invasive cattails [24,25].

Greene Prairie was also cultivated, facilitating sediment erosion downslope onto wetland soil [25]. Immediately upstream, increased runoff converted Dunn's Marsh (City wetland) into a stormwater pond that discharges into the Arboretum's low-lying land, which became a stormwater flow path. In 1998, the Arboretum rejected a plan by the City of Madison to excavate a channel and use the spoil to create an adjacent parallel berm. That project footprint was 1.6 ha (4 ac). Along the outflow, reed canary grass became dominant and invaded about 3.6 ha (9 ac) of lower Greene Prairie, including two former natural potholes (Leaflet \#18 in [21]). Several attempts to control reed canary grass failed to achieve that goal [26]. To accommodate wetter conditions, the Arboretum could change the target to swamp white oak woodland or attempt to create aquatic habitat too deep for cattails. The latter would require permitting under the Clean Water Act plus substantial funds to truck spoils off-site.

\subsection{Impacts of Urban Runoff on a Restoration Icon}

Curtis Prairie is considered the world's oldest restored prairie, with plantings beginning in 1935. The eastern third is an unplowed wetland/upland remnant, with extensive tussock sedge (Carex stricta), native cattail ( $T$. latifolia) and native Canada bluejoint (Calamagrostis canadensis). The earliest plans for what is now Curtis Prairie called for lowland vegetation and indicated nine water flow paths [27]. In 1969, four of those inflows were routed through a single retention facility (now Curtis Pond), which slows peak flows and retains some pollutants. While not regularly monitored, the pond and downstream wetlands appear to improve water quality. Our recent sampling of seven rainfall events between July 2011 and April 2012 in ten points across Curtis Prairie, showed that runoff flowing into Curtis Pond has some N- and P-removal before discharging to Curtis Creek, where it spreads through a stand of reed canary grass and then flows over the surface across Canada bluejoint and tussock sedge vegetation. The surface flow has lower concentrations of total nitrogen (TN), total phosphorus (TP) and TSS before it flows into a culvert that discharges into Teal Pond Wetlands (Figure 3).

The dredging of Curtis Pond will provide greater capacity for trapping TSS from a 58-ha (144-ac) watershed, but it will also have unintended negative impacts (Leaflet \#23 in [21]). Dredging is proposed to obliterate a small wetland that has formed near the inflow-a wetland that likely removes $\mathrm{N}$. The dredging will temporarily disrupt stored $\mathrm{P}$ and $\mathrm{N}$, which will flow through Curtis Creek and then onto the surface, where it will enrich the wetland portion of Curtis Prairie [11]. The wetland portion of Curtis Prairie already has fewer plant species than the upland (Snyder [28] recorded 230 native species in $10111-\mathrm{m}^{2}$ plots), in part because nutrient inflows increase plant productivity and allow aggressive species to become dominant and outcompete subordinate species, e.g., a monotype of reed canary grass occurs downstream from Curtis Pond (Figure 3). Further downstream, a fire lane impounds stormwater, and a native willow (Salix exigua) invaded and dominated for $\sim 15$ years. Most 
of the willows were cut and herbicided in 2012, but continual management will be needed to sustain the herbaceous wet prairie vegetation.

Figure 3. A small wetland formed at the inflow to Curtis Pond, where sediment and vegetation likely accumulate additional nutrients and sediments. With dredging, however, these functions would change in uncertain ways, potentially increasing discharges of $\mathrm{N}$ to Curtis Prairie. The outflow to Curtis Prairie is a culvert that discharges to Curtis Creek (formed after the pond was constructed in 1969).

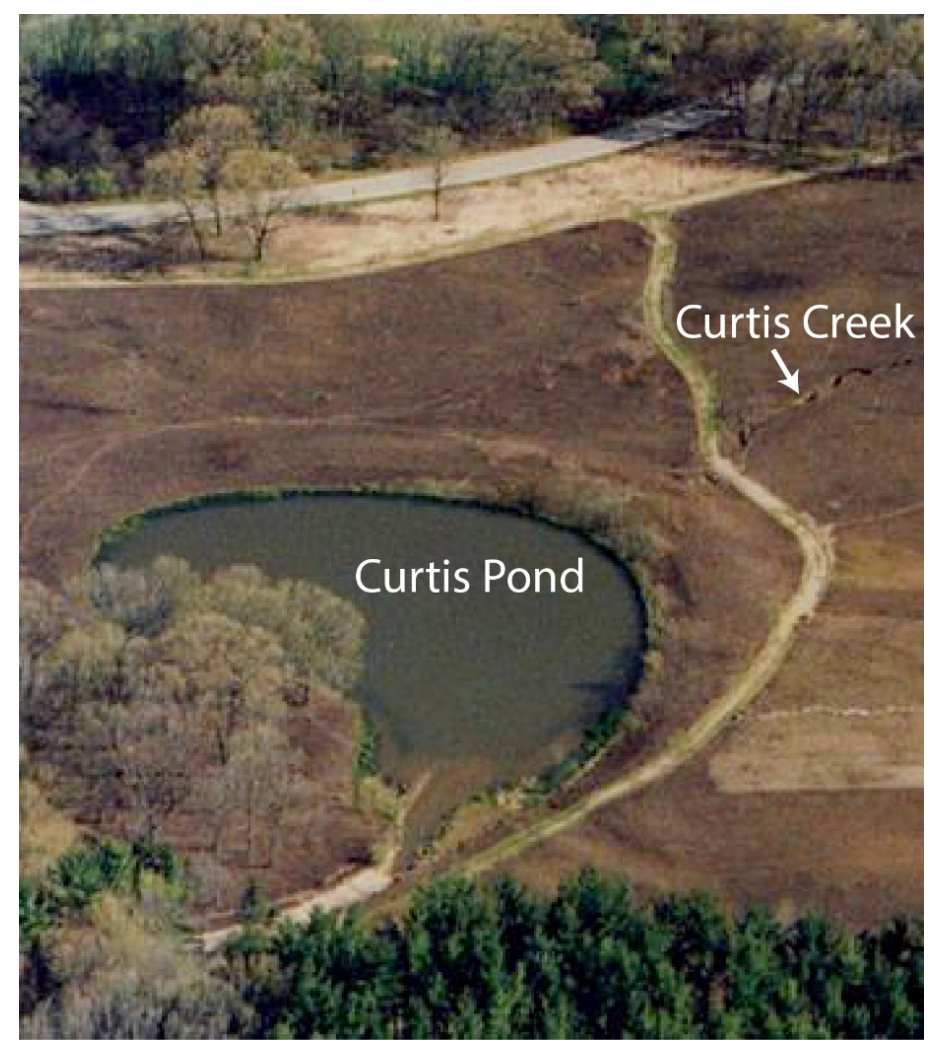

The need to dredge Curtis Pond should be based on future sediment delivery and knowledge of how well it removes both $\mathrm{N}$ and $\mathrm{P}$, as well as how N- and P-removal protect Arboretum wetlands and Lake Wingra. $\mathrm{N}$ removal is supported more by shallow ponds than deeper pits [29]. Current models used to predict nutrient removal do not include the biological roles of vegetation. Dredging could be more detrimental than beneficial if the current level of $\mathrm{P}$ - and N-removal protects Curtis Prairie wetlands and if sediment inflows can be curtailed upstream. Will more $\mathrm{N}$ and $\mathrm{P}$ be released during dredging than will be trapped after dredging? Will a deeper Curtis Pond remove less N? Does P trapped well upstream actually benefit the intended downstream beneficiary, Lake Wingra? A holistic assessment is needed.

Of all the Arboretum wetlands, this restoration icon is a top priority for protection through sustainable management. Weedy wetlands might be the most self-sustainable state, but native vegetation can be restored through sustainable management where people willingly pull weeds. The Arboretum has sufficient understanding of the stressors and the resources needed to manage for native species diversity, herbaceous canopy structure, and valued functions (productivity, WQI, passive recreation). Annual to biennial burning can keep shrubs (native and exotic) at bay; weeding (including herbiciding) can keep reed canary grass, willows, and other invasive species from expanding. 


\subsection{Treatment of Urban Runoff by Constructed Wetlands}

Kline [30] (p. 174) described the construction of Pond 2 in 1980 as "destroying half the good quality sedge meadow south of Teal Pond." Later, Pond 2 was enlarged and dredged, adding four vegetated swales nearby (Box 4). For stormwater ponds to benefit the Arboretum, they should remove nutrients to reduce stress on downstream wetlands and support native species. Lacking those services, they should at least reduce $P$ inflows to downstream waters, in keeping with the intent of water quality regulations. Yet, there are no measures of improved water quality to assess their effectiveness. Instead, practice-based measures are used (e.g., was the pond built?). There are, however, quantitative data that show the disparity between such measures of compliance. For four swales designed to improve water quality (Figure 4), practice-based measures indicated compliance, since seeds were sown as planned (27 native wetland plant species at $\sim 540 / \mathrm{m}^{2}[50 / \mathrm{sq} \mathrm{ft}]$ in 2009 ), with no requirement for those species to establish. Performance-based standards were assessed beginning in 2010, when the sown species did not establish [31]. Instead, the invasive hairy vetch (Vicia villosa) dominated the inter-swale berms, where its seeds likely hitchhiked on construction equipment (Leaflet \#23 in [21]), and cattails dominated large portions of the swales, likely from wind dispersal (Doherty et al., in review [32]; Leaflet \#27 in [21]). In 2011-2012, additional data on plant species composition, net primary productivity (NPP), WQI, and hydrologic functions demonstrated limited removal of TSS, N and P. All three swales were net exporters of $\mathrm{P}$ and one also exported $\mathrm{N}$ (Box 4). Also, where water ponded, cattail NPP was twice that of vegetation where water infiltrated rapidly, so the assumption that high NPP indicates high WQI was not supported.

Box 4. A team of ecohydrologists, biological system engineers, and plant ecologists assessed how well three vegetated swales functioned. Doherty et al., in review [32], documented net export of both nitrogen $(\mathrm{N})$ and phosphorus (P) over a dozen stormflow events in 2011-2012, with greater export in a ponded swale than in two rapidly-draining swales. The ponded swale had high net primary productivity (NPP) because of its dominant cattails (Typha spp.), but five other services were diminished; these were water quality improvement, stormwater retention, flow attenuation, erosion resistance, and plant diversity support. The two rapidly-draining swales had open canopies that allowed moss and algal mats to help stabilize the soil [33], which, along with rapid infiltration, reduced the export of total suspended solids, $\mathrm{N}$, and P. N and P likely came from the topsoil $(15 \mathrm{~cm}$ thick $)$ that facility engineers/designers insisted on adding, despite scientific evidence that nutrient-rich soil reduces diversity [34] and causes plants to allocate biomass to shoots instead of roots that could potentially stabilize the soil (Leaflet \#15 in [21]). Our explanation of these different outcomes is that porous subsoils precluded ponding but facilitated infiltration and pulsed hydroperiods. Intermittent drainage led to more open vegetation with more light reaching the soil surface, greater cover of stabilizing moss and algal mats, reduced erosion, and greater WQI (Leaflet \#28 in [21]). In 2013, the swales were managed to receive and retain more water, and cattails are expanded as we predicted (Leaflets \#27-28 in [21]). That year had variable inflows, with high rainfall in June followed by a long summer drought. Typha frequency increased to $86 \%$ (up from 82\% in 2012 and 80\% in 2010 and 2011; 96 plots sampled each year; Doherty, unpublished data). We expect further increases in frequency and abundance in wetter growing seasons, along with further decreases in diversity. 
Figure 4. Urban runoff flows from left to right, into two forebays, then four swales, then into a collection pond that discharges to a concrete flume (bottom of photo). In between, four parallel swales were excavated, separated with berms, and surfaced with $15 \mathrm{~cm}$ of salvaged topsoil. Research occurred from 2010 to 2012, after which inflows were increased and outflows were decreased to retain more stormwater.

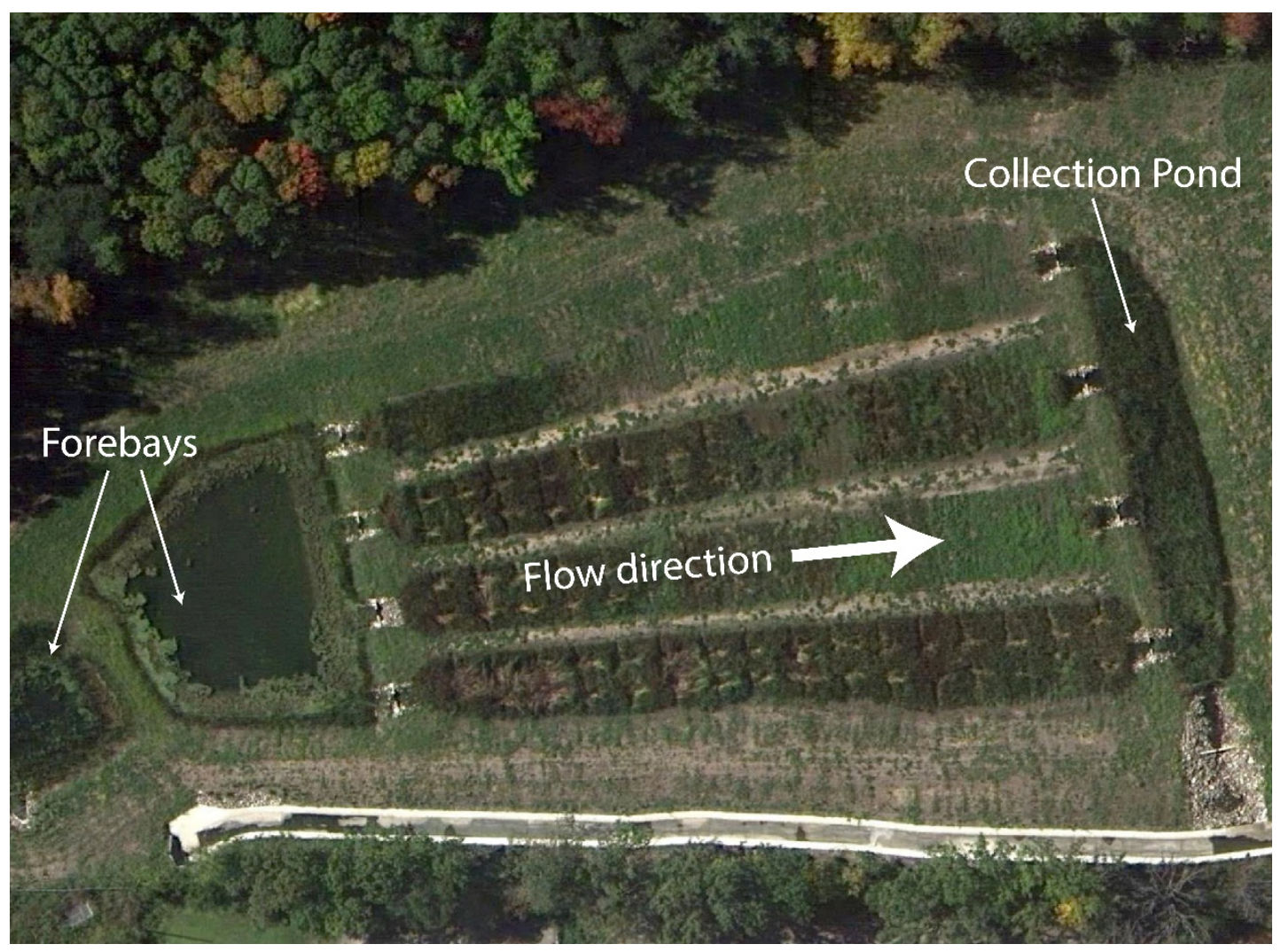

Vegetation around the edge of Pond 4 has also become dominated by invasive cattails. Propagules of native emergent species were planted in October 2010; however, the entire $(\sim 1 \mathrm{~km})$ shoreline was quickly invaded by cattails, which grew to $>2 \mathrm{~m}$ tall (average $=1.24 \mathrm{~m}$ ) and dominated 94 of 96 contiguous plots. Only two native taxa remained abundant at the end of the first growing season (Scirpus spp. occurred in 72 plots and Pontedaria cordata in 46, [35]). The surrounding berm was rapidly invaded by sweet clover (Melilotus officinalis, M. alba), so the 3.2-ha (8-ac) project failed to support native vegetation. It is unclear which native plants remain or which wildlife species use the site. Elsewhere, exotic plants attract additional exotic species to colonize, resulting in "invasional meltdowns" [36].

\section{Approaches to Achieve Sustainability}

The Arboretum's experiences in stormwater management suggest two approaches for providing and sustaining high-quality water. First, a feasible path for nature reserves is to accept the infrastructure and the inevitable undesirable and persistent outcome (weeds) - an approach that violates the Arboretum vision and mission. Second, the more difficult path is to remove off-site stressors in order to make native communities more restorable, via sustainable management - an approach that requires holistic planning. Regardless of the path chosen, progress and outcomes need to be based on performance; practice-based assessments are not sufficient. 


\subsection{Weeds Are an Undesirable and Persistent Outcome}

Whether the Arboretum's wetlands are natural remnants, degraded, within a restoration icon, or swales established for stormwater treatment, attempts to treat stormwater have attracted weedy invaders to become dominant and displace native vegetation. These urban wetlands have shifted toward undesirable and persistent invasive cattails where soil is continually inundated, reed canary grass where water levels are more variable, and woody plants (buckthorn or willows) where inundation is intermittent. Once aggressive invaders are established, they persist indefinitely. Cattail perpetuates itself in part by garnering and holding onto nitrogen more effectively than competitors [37,38] and by producing high levels of biomass aboveground, where the thick litter displaces all but its own vegetative sprouts [39]. Similarly, reed canary grass self-perpetuates by accumulating thick litter that other species are less able to penetrate than its own sprouts [40-42]. As a result, these invaders are very difficult to reverse $[20,26,43]$. Because the Arboretum's mission is to restore the land, and because Leopold's vision was to re-create examples of plant communities prior to European settlement, the approach of accepting inflows of polluted urban runoff would require perpetual control invasive plants using herbicides, prescribed fire, mowing, and other tools [44]. And because resources are insufficient to address all wetland areas, aggressive invaders will persist and expand. Management for self-sustainable native wetland vegetation seems incompatible with nutrient-rich urban runoff.

Urban nature reserves could consider more aggressive habitat alterations and more futuristic targets ("restore to the future"; [45]). Three possibilities follow: (1) Remove nutrient-rich topsoil [34] to favor hardy natives (e.g., [46]). At the Arboretum, tussock sedge might grow well on low-nutrient soil ([47]; Leaflet \#22 in [21]). Still, urban runoff would continually add nutrients, and a sedge meadow would likely be invaded by reed canary grass [48]; (2) Shift the target to woodland. The Arboretum could plant native swamp white oak (Quercus bicolor) seedlings and saplings and allow trees to shade out some herbaceous weeds. However, an understory of buckthorn would likely develop, as at Teal Pond Wetland. Also, engineers advise against planting trees on berms, because they can topple and destabilize the berm; (3) Excavate deep-water aquatic ecosystems without shallow-water shores. This would create hazards for people (falling, drowning), which is why stormwater ponds have shallow-water benches that inevitably attract cattails. Deep ponds would produce excess spoils leading to larger berms (or costly export of spoils). Nutrient-rich ponds also attract aquatic invasive plants, such as Eurasian milfoil (Myriophyllum spicatum; [49]) and/or algal blooms, as current stormwater ponds often do.

In both wetlands and aquatic ecosystems, native vegetation is incompatible with nutrient-rich urban runoff. Management for native vegetation requires continual weed control, which is unsustainable over large areas. This leads us to conclude that the external stressors must be treated at their source in order for Arboretum lands to achieve Leopold's vision.

\subsection{Remove Off-Site Stressors}

The Arboretum's mission is consistent with the 2012 Convention on Biological Diversity, as reported by Aronson and Alexander [50]. Those authors conclude that "Ecosystem restoration is now globally recognized as a key component in conservation programs and essential to the quest for the long-term sustainability of our human-dominated planet. It remains for all to aim for global results 
while acting locally." Homeowners could control TSS, P, and N at the upstream sources, by installing rain barrels to capture rooftop runoff and rain gardens to collect runoff from sidewalks and lawns [51]. Street runoff could be treated in existing public greenways. Upstream treatment might have been more cost effective than construction projects in the Arboretum (to date $>\$ 6$ million dollars, not including planning). There must be greener, more affordable alternatives.

We propose managing stormwater flowing into the Arboretum to achieve "zero tolerance of unclean runoff," consistent with its principles [5]. The City could engage upstream neighbors to cease both $\mathrm{P}$ and $\mathrm{N}$ additions; to require residents to rake and store tree leaves in bags for pick-up and removal to an off-site disposal area; to retain roof runoff in rain barrels above and below ground (for irrigation during dry weather); to infiltrate some of the runoff using rain gardens that can also remove TSS upstream; and to replace (as needed) impermeable sidewalks and streets with permeable pavers. Steps have been taken toward each of these actions. For example, Madison already bans the use of P-containing lawn fertilizers and encourages homeowners to keep raked leaves out of the gutters, where $\mathrm{P}$ is leached by runoff. Rain gardens are popular in some neighborhoods, as is native plant gardening, so it seems a logical and important step to create further depressions with native wetland species to trap TSS, N and $\mathrm{P}$ (Box 5) and to assess their performance.

Box 5. The validity of the assumption that TSS removal reduces algal blooms depends on how much $\mathrm{P}$ is removed from the water body in question, as well as where and when $\mathrm{P} v s . \mathrm{N}$ is catalyzing algal blooms $[9,12]$. N-removal is not regulated for improving water quality, yet evidence is growing that $\mathrm{N}$ and $\mathrm{P}$ vary in their effects on ecosystems and that both need to be addressed [11,13,46,52-54]. An additional argument is that $\mathrm{P}$ removal well upstream from lakes might have less value than removal of $\mathrm{N}$ to benefit wetlands such as those in Curtis Prairie. In our research, TSS and P removal in three swales were not tightly correlated; we found a slight net removal of TSS but an export of dissolved P, as well as a net export of total $\mathrm{N}$.

Given reduced stormwater inflow and runoff quality restored to pre-settlement conditions, the Arboretum could allow its deep stormwater ponds to fill gradually and become "polishing" pools and wetlands. Shallow pools of varied size and depth are better for $\mathrm{N}$ removal, and denitrification occurs in urban streams where there is sufficient moisture for anaerobic soil and where roots provide organic food for denitrifying microorganisms [55].

Stream floodplains and banks could be managed using sandbar willows (Salix exigua) a clonal shrub with flexible stems that are resilient to stormwater pulses. Woody debris and sandbar willows could stabilize vertical banks and stream bottoms [56-58] by trapping inflowing sediments, reducing channel erosion, and accumulating sediment where it is needed - in the streambed, where it would elevate the topography and reduce dewatering of the floodplain, thereby enhancing denitrification. Had Leopold seen stormwater runoff cutting channels through the Arboretum, perhaps he would have suggested planting banks with sandbar willows.

A community-based initiative to protect and restore Lake Wingra began several years ago, and the City is now supporting watershed planning, potentially providing more affordable, dependable and sustainable approaches than excavating ponds that require perpetual dredging. For example, concrete flumes leading to the Arboretum could be transformed into greenways. If storms become more 
frequent and more intense as climate changes, the Arboretum would still receive inflows during major storm events, and sediments would fill the Arboretum's existing stormwater ponds. If allowed to become shallow-water vegetated wetlands, their ability to treat both $\mathrm{N}$ and $\mathrm{P}$ could well increase. Volunteers and citizen scientists could assist in surveillance of invasive plants and weeding to favor dominance by native plants. Sustained management upstream at the source of the problem would allow the Arboretum to move closer to self-sustainable native vegetation in its many wetlands.

Leopold's vision is a tantalizing target for an urban reserve that is dedicated to research and education. With upstream treatment of urban runoff, the Arboretum will be poised to achieve Leopold's vision for restoration of historical plant communities. With stressors reduced off-site, native vegetation could be restored and sustained, even in an urban wetland (as in Curtis Prairie, prior to urbanization). Still, invasive species will be perpetual threats requiring sustained management. If this green alternative can be accomplished anywhere, the Arboretum would seem to be the place; it has the relevant mission, ample knowledge of restoration science and practice, an appreciative public, and support of hundreds of volunteers.

\subsection{Performance-Based Assessment}

Arboretum staff intermittently sample a subset of inflows to assess nutrient concentrations, and vegetation is occasionally sampled in two prairies that receive urban runoff (Curtis Prairie has not been monitored since 2002, reported in [28]). Continual assessment of Arboretum wetlands is needed to track progress in improving water quality and restoring biodiversity. Monitoring needs to be based on informative measures of priority attributes, e.g., TSS, and loading of $\mathrm{N}$ and P, including dissolved forms (if not loading, at least representative concentrations) in water. Shifts in composition (especially invasive species distributions) need to be monitored, especially in downstream wetlands. To track the effects of removing upstream stressors, the Arboretum would need automated samplers to collect inflowing water and funds to assay $\mathrm{N}$ and $\mathrm{P}$ concentrations. New methods for sampling invasive species remotely [59] should be developed for herbaceous vegetation. Funds for monitoring need to be in hand, to attract researchers to analyze and interpret data.

Our vision is to expand Leopold's (1949) land ethic to include homeowner responsibility for pollutants along with community pride in pollutant removal. For example, an interpretive sign at a parking lot adjacent to the Minneapolis Convention Center proudly advertises its underground stormwater infiltration pipes as "More than meets the eye" [60]. Punitive measures are an alternative, i.e., fees charged for excess TMDLs. Another example from Minneapolis is a church that uses underground storage barrels that fill during rain events and serve as reservoirs for later irrigation, saving over $\$ 10,000$ in stormwater management fees [61]. Voluntary measures and pride in accomplishment seem preferable to punitive measures for a community that appreciates UW's urban nature reserve. It is time to enforce the Arboretum's [5] basic principle that the quality of urban runoff be restored to pre-settlement conditions. We propose rededicating Leopold's Arboretum to research, education, restoration, and sustainable management of its waters and wetlands.

An evolving land ethic that can address new challenges seems relevant to urban nature reserves everywhere. 


\section{Conclusions}

At the Arboretum, attempts to improve water quality have imposed $\sim 10$ ha of infrastructure (ponds, armored channels, graded banks, swales) that disturbed the land and allowed weeds to invade and dominate. Weeds are an undesirable and persistent outcome that violates the Arboretum mission.

Diverse wetland ecosystems are not self-sustainable where threatened by alien species, contaminants, excess nutrients, and stormwater pulses. However, with TSS, N and P reduced to non-polluting levels, the Arboretum could achieve its mission and vision via sustainable management, namely, land-care efforts at affordable levels.

Insistence on pre-settlement water quality, and treating TSS, N and P at their upstream sources, would allow the Arboretum to achieve the wetland component of its mission to restore land for research and education, as well as Leopold's vision of ecosystems restored to pre-European composition.

\section{Acknowledgments}

The US EPA Great Lakes Restoration Initiative (Award \# GL-00E00647) funded research in vegetated swales; the UW-Madison Morgridge Center funded water sampling in Curtis Prairie; Anita Thompson, Steve Loheide, Jeffrey Miller, and Stephanie Prellwitz helped interpret data. Isabel M. Rojas was funded from Becas Chile fellowship from the Comisión Nacional de Investigación Científica y Tecnológica de Chile. Volunteers helped with field sampling; Arboretum staff (M. Wegener, B. Herrick, M. Hansen) assisted with maps and Arboretum records.

\section{Conflicts of Interest}

The authors declare no conflict of interest.

\section{References}

1. Caldicott, J.B. 'The Arboretum and The University': The speech and the essay. Trans. Wis. Acad. Sci. Arts Letters 1999, 87, 5-21.

2. Zedler, J.B.; Doherty, J.M.; Miller, N.A. Shifting restoration policy to address landscape change, novel ecosystems, and monitoring. Ecol. Soc. 2012, 17, doi: 10.5751/ES-05197-170436.

3. Curtis, J.T.; Partch, M.C. Effect of fire on the competition between bluegrass and certain prairie plants. Am. Midl. Nat. 1948, 39, 437-443.

4. Rohlich, G.A. Eutrophication: Causes, Consequences, Correctives; Academy of Sciences: Washington, DC, USA, 1969.

5. University of Wisconsin Arboretum. Facility Storm Water Management Plan; University of Wisconsin Arboretum: Madison, WI, USA, 2006.

6. Carpenter, S.R.; Caraco, N.F.; Correll, D.L.; Howarth, R.W.; Sharpley, A.N.; Smith, V.H. Nonpoint pollution of surface waters with phosphorus and nitrogen. Ecol. Appl. 1998, 8, 559-568.

7. Carpenter, S.R. Phosphorus control is critical to mitigating eutrophication. Proc. Natl. Acad. Sci. USA 2008, 105, 11039-11040.

8. Lathrop, R.C. Perspectives on the eutrophication of the Yahara Lakes. Lake Reserv. Manag. 2007, $23,345-365$. 
9. Lewis, W.M., Jr.; Wurtsbaugh, W.A. Control of lacustrine phytoplankton by nutrients: Erosion of the phosphorus paradigm. Int. Rev. Hydrobiol. 2008, 93, 446-465.

10. Paerl, H.W.; Xu, H.; McCarthy, M.J.; Zhu, G.; Qin, B.; Li, Y.; Gardner, W.S. Controlling harmful cyanobacterial blooms in a hyper-eutrophic lake (Lake Taihu, China): The need for a dual nutrient (N \& P) management strategy. Water Res. 2011, 45, 1973-1983.

11. Bernhardt, E.S. Cleaner lakes are dirtier lakes. Science 2013, 342, 205-206.

12. Finlay, J.C.; Small, G.E.; Sterner, R.W. Human influences on nitrogen removal in lakes. Science 2013, 342, 247-250.

13. Collins, K.A.; Lawrence, T.J.; Stander, E.K.; Jontos, R.J.; Kaushal, S.S.; Newcomer, T.A.; Grimm, N.B.; Ekberg, M.L.C. Opportunities and challenges for managing nitrogen in urban stormwater: A review and synthesis. Ecol. Eng. 2010, 36, 1507-1519.

14. Leopold, A. Sand County Almanac; Oxford University Press: Oxford, UK, 1949.

15. Lathrop, R.D.; Liebl, D.; Welke, K. Carp removal to increase water clarity in shallow eutrophic Lake Wingra. Lakeline 2013, Fall 2013, 23-30.

16. Hall, S.J.; Zedler, J.B. Constraints on sedge meadow self-restoration in urban wetlands. Restor. Ecol. 2010, 18, 671-680.

17. Pathak, N. Assessment of the Hydroecology of Wingra Marsh at the University of Wisconsin Arboretum. Master's Thesis. University of Wisconsin-Madison, Madison, WI, USA, 1 December 2009.

18. Boers, A.M.; Veltman, R.L.D.; Zedler, J.B. Typha $x$ glauca dominance and extended hydroperiod constrain restoration of wetland diversity. Ecol. Eng. 2007, 29, 232-244.

19. Boers, A.M.; Zedler, J.B. Stabilized water levels and Typha invasiveness. Wetlands 2008, 28, 676-685.

20. Irwin, H. A Natural History Study of the University of Wisconsin Arboretum. Master's Thesis. University of Wisconsin-Madison, Madison, WI, USA, 16 May 1973.

21. Arboretum Leaflets (\#1-30). Available online: http://uwarboretum.org/publications/leaflets/ (accessed on 22 September 2013).

22. Woo, I.; Zedler, J.B. Can nutrients alone shift a sedge meadow towards dominance by the invasive Typha $x$ glauca? Wetlands 2002, 22, 509-521.

23. Lindig-Cisneros, R.; Zedler, J.B. Phalaris arundinacea seedling establishment: Effects of canopy complexity in fen, mesocosm, and restoration experiments. Can. J. Botany 2002, 80, 617-624.

24. Students in Water Resources Management. Restoration of the Arboretum's Eastern Wetlands; Nelson Institute of Environmental Studies, University of Wisconsin-Madison: Madison, WI, USA, 2008.

25. Werner, K.J.; Zedler, J.B. How sedge meadow soils, microtopography, and vegetation respond to sedimentation. Wetlands 2002, 22, 451-466.

26. Wilcox, J.C.; Healy, M.T.; Zedler, J.B. Restoring native vegetation to an urban wet meadow dominated by reed canarygrass (Phalaris arundinacea 1.) in Wisconsin. Nat. Areas J. 2007, 27, 354-365.

27. Curtis, J.T. Arboretum Master Development Plan, I-The Prairie; University of Wisconsin Arboretum: Madison, WI, USA, 1951. 
28. Snyder, T.A., III. A Spatial Analysis of Grassland Species Richness in Curtis Prairie. Master's Thesis. University of Wisconsin-Madison, Madison, WI, USA, 3 May 2004.

29. Hansson, L.A.; Bronmark, C.; Nilsson, P.A.; Abjornsson, K. Conflicting demands on wetland ecosystem services: Nutrient retention, biodiversity or both? Freshw. Biol. 2005, 50, 705-714.

30. Kline, V.M. Long Range Management Plan Arboretum Ecological Communities; University of Wisconsin Arboretum: Madison, WI, USA, 1992.

31. Boehm, H.I.A. Achieving Vegetated Swales for Urban Stormwater Management: Lessons Learned \& Research Setbacks. Master's Thesis. University of Wisconsin-Madison, Madison, WI, USA, 14 July 2011.

32. Doherty, J.M.; Miller, J.F.; Prellwitz, S.G.; Thompson, A.M.; Loheide, S.L.; Zedler, J.B. Bundles and tradeoffs among six wetland services were associated with hydrologic regime. Ecosystems 2013, submitted for publication.

33. Prellwitz, S.G.; Thompson, A.M. Biota and hydrology influence soil stability in constructed wetlands. Ecol. Eng. 2013, submitted for publication.

34. Berendse, F.; Oomes, M.J.M.; Altena, H.J.; Elberse, W.T. Experiments on the restoration of species-rich meadows in the netherlands. Biol. Conserv. 1992, 62, 59-65.

35. Riha, K. University of Wisconsin, Madison, WI. Unpublished work, 2010.

36. Simberloff, D.; Von Holle, B. Positive interactions of nonindigenous species: Invasional meltdown? Biol. Invasions 1999, 1, 21-32.

37. Larkin, D.J.; Lishawa, S.C.; Tuchman, N.C. Appropriation of nitrogen by the invasive cattail Typha x glauca. Aquat. Botany 2012, 100, 62-66.

38. Larkin, D.J.; Freyman, M.J.; Lishawa, S.C.; Geddes, P.; Tuchman, N.C. Mechanisms of dominance by the invasive hybrid cattail Typha x glauca. Biol. Invasions 2012, 14, 65-77.

39. Vaccaro, L.E.; Bedford, B.L.; Johnston, C.A. Litter accumulation promotes dominance of invasive species of cattails (Typha spp.) in lake ontario wetlands. Wetlands 2009, 29, 1036-1048.

40. Zedler, J.B. Feedbacks that might sustain natural, invaded and restored states in herbaceous wetlands. In New Models for Ecosystem Dynamics and Restoration; Hobbs, R., Suding, K.N., Eds.; Island Press: Washington, DC, USA, 2009; pp. 236-258.

41. Eppinga, M.B.; Kaproth, M.A.; Collins, A.R.; Molofsky, J. Litter feedbacks, evolutionary change and exotic plant invasion. J. Ecol. 2011, 99, 503-514.

42. Kaproth, M.A.; Eppinga, M.B.; Molofsky, J. Leaf litter variation influences invasion dynamics in the invasive wetland grass Phalaris arundinacea. Biol. Invasions 2013, 15, 1819-1832.

43. Healy, M.T.; Zedler, J.B. Set-backs in replacing Phalaris arundinacea monotypes with sedge meadow vegetation. Restor. Ecol. 2010, 18, 155-164.

44. Wisconsin Reed Canary Grass Management Working Group. Reed Canary Grass (Phalaris arundinacea) Management Guide: Recommendations for Landowners and Restoration Professionals; PUB-FR-428 2009; Available online: http://dnr.wi.gov/topic/forestmanagement/ documents/pub/FR-428.pdf (accessed on 3 August 2013).

45. Choi, Y.D.; Temperton, V.M.; Allen, E.B.; Grootjans, A.P.; Halassy, M.; Hobbs, R.J.; Naeth, M.A.; Torok, K. Ecological restoration for future sustainability in a changing environment. Ecoscience 2008, 15, 53-64. 
46. Wassen, M.J.; Venterink, H.O.; Lapshina, E.D.; Tanneberger, F. Endangered plants persist under phosphorus limitation. Nature 2005, 437, 547-550.

47. Gallagher, S.K. Use of Nitrogen and Water Treatments to Manipulate Carex stricta Lam Propagules. Master's Thesis. University of Wisconsin-Madison, Madison, WI, USA, 4 December 2009.

48. Kercher, S.M.; Herr-Turoff, A.; Zedler, J.B. Understanding invasion as a process: The case of Phalaris arundinacea in wet prairies. Biol. Invasions 2007, 9, 657-665.

49. Olson, E.R.; Ventura, S.J.; Zedler, J.B. Merging geospatial and field data to predict the distribution and abundance of an exotic macrophyte in a large wisconsin reservoir. Aquatic Botany 2012, 96, 31-41.

50. Aronson, J.; Alexander, S. Ecosystem restoration is now a global priority: Time to roll up our sleeves. Restor. Ecol. 2013, 21, 293-296.

51. Selbig, W.R.; Balster, N.J. Evaluation of Turf Grass and Prairie Vegetated Rain Gardens in a Clay and Sand Soil: Madison, Wisconsin, Water Years 2004-2008; US Geological Services: Middleton, WI, USA, 2009.

52. Ardon, M.; Montanari, S.; Morse, J.L.; Doyle, M.W.; Bernhardt, E.S. Phosphorus export from a restored wetland ecosystem in response to natural and experimental hydrologic fluctuations. $J$. Geophys. Res. Biogeosci. 2010, 115, doi: 10.1029/2009JG001169.

53. Gusewell, S.; Bailey, K.M.; Roem, W.J.; Bedford, B.L. Nutrient limitation and botanical diversity in wetlands: Can fertilisation raise species richness? Oikos 2005, 109, 71-80.

54. Atkinson, R.B.; Perry, J.E.; Noe, G.B.; Daniels, W.L.; Cairns, J., Jr. Primary productivity in 20-year old created wetlands in southwestern virginia. Wetlands 2010, 30, 200-210.

55. Gift, D.M.; Groffman, P.M.; Kaushal, S.S.; Mayer, P.M. Denitrification potential, root biomass, and organic matter in degraded and restored urban riparian zones. Restor. Ecol. 2010, 18, 113-120.

56. Watson, C.C.; Abt, S.R.; Derrick, D. Willow posts bank stabilization. J. Am. Water Resour. Assoc. 1997, 33, 293-300.

57. Pezeshki, S.R.; Shields, F.D. Black willow cutting survival in streambank plantings, southeastern united states. J. Am. Water Resour. Assoc. 2006, 42, 191-200.

58. Pezeshki, S.R.; Li, S.W.; Shields, F.D.; Martin, L.T. Factors governing survival of black willow (Salix nigra) cuttings in a streambank restoration project. Ecol. Eng. 2007, 29, 56-65.

59. Schimel, D.S.; Asner, G.P.; Moorcroft, P. Observing changing ecological diversity in the anthropocene. Front. Ecol. Environ. 2013, 11, 129-137.

60. Zedler, J.Z. the Minneapolis Convention Center in Minneapolis, MN, USA. Personal Observation, 6 August 2013.

61. Cookas, M. St. Mary's Greek Orthodox Church. Available online: http://www.afs.nonprofitoffice. com/vertical/Sites/\%7B7FB21E8B-C13D-4E8E-B9BC-C00DD2CB65AE\%7D/uploads/\% 7B1159F1A4-72A4-4F32-B0D3-70DE64CB5357\%7D.PDF (accessed on 1 September 2013).

(C) 2014 by the authors; licensee MDPI, Basel, Switzerland. This article is an open access article distributed under the terms and conditions of the Creative Commons Attribution license (http://creativecommons.org/licenses/by/3.0/). 